\title{
Beech bark disease in Slovakia related to fungi of the genus Nectria s.l. and the anatomy of necrotised bark and wood: a brief review
}

\author{
Vladimír Račko $^{1 *}$, Ivan Mihál' ${ }^{2}$ Ol'ga Mišíková $^{1}$ \\ ${ }^{1}$ Department of Wood Science, Faculty of Wood Science and Technology, Technical University Zvolen, \\ T. G. Masaryka 24, 96053 Zvolen, Slovak Republic \\ ${ }^{2}$ Institute of Forest Ecology of the Slovak Academy of Sciences, Sturova 2, 96053 Zvolen, Slovak Republic
}

\begin{abstract}
RačKo, V., MıнÁL, I., Mišíková, O., 2020. Beech bark disease in Slovakia related to fungi of the genus Nectria s.l. and the anatomy of necrotised bark and wood: a brief review. Folia Oecologica, 47 (1): 16-22.

This short review summarises the history and current knowledge regarding beech bark disease (BBD) in Slovakia. Moreover, the results of ongoing long-term disease monitoring are summarised. The article also provides a list of the 29 Nectria s.l. species found to date in Slovakia, complete with information about their occurrence on host tree species. Above all, we highlight the need for histopathological research on beech tissues attacked by different Nectria spp. Notably, neither the defensive response mechanisms of host cellular tissues at the anatomical and biochemical levels nor the strategy of decomposition by different pathogens have been explored in beech.
\end{abstract}

\section{Keywords}

beech necrosis, Fagus sylvatica L., histopathology, Nectria s.l., xylem tissues

\section{Introduction}

At present, a number of phytopathological signs that are largely caused by various fungi have been recorded in all developmental stages of Fagus sylvatica L. stands, from natural regeneration up to maturity (KACPRZYK et al., 2017). The most commonly known disease caused by parasitic fungi is beech bark necrotic disease (SUROVEC, 1992). A mass occurrence of bark necroses in young beech stands was recorded by LEONTOVYČ (1992) as early as 1988-1989, when the dieback of thickets younger than 20 years old was primarily observed in the industrial zone in Slovakia. Since the middle of the previous century (throughout the period of acidic deposition), beech bark disease (BBD) has been observed on Fagus grandifolia Ehrh. over much of its distribution range (Houston, 1994). In the north-eastern USA and eastern Canada, beech trees are considered to be experiencing the aftermath of the initial
BBD infection wave (CALE et al., 2015a, b; STEINER et al., 2017). The causality of the rise and induction of necroses as an external symptom of beech bark necrotic disease has been discussed ever since research on this issue began (YAMADA, 2001; YAMAJI and ICHIHARA, 2012). Necrotic damage to beech bark tissues and other woody plants is associated with the activity or interaction among various insect and fungal pathogens. For example, at present, the problem of epiphytic necrosis of ash by parasitic fungi Hymenoscyphus fraxineus and Dothiorella sarmentorum is a topical problem in Slovakia (IvAnoví, 2018).

Some Nectria spp. are very dangerous parasites with typical tracheomycotic symptoms. However, many are not dangerous and only mycotrophic with other fungal species. The most important causes of necrosis generally include bark damage by biotic (e.g., fungi, insects, wildlife), abiotic (e.g. frost, hail, fire) or anthropogenic factors (e.g., human management activities) that promote

*Corresponding author: 
infection by fungi that eventually kill the tree (CALE et al., 2015b). The first descriptions of BBD in Europe as one of the most important complex diseases of beech ( $F$. sylvatica) were given by HaRTIG (1878). Damage to beech branches by fungi of the genus Nectria spp. was observed by FunK (1940) in Italy. BBD is usually triggered by various abiotic and biotic factors. Outbreaks were mainly observed after a mass attack of Cryptococcus fagisuga followed by infection of the lesions by Neonectria spp. The BBD pathogenic fungi are Neonectria coccinea group on beech in Europe, Neonectria faginata (M.L. Lohmann, A.M.J. Watson \& Ayers) Castl. \& Rossmann on beech in North America and Neonectria ditissima (Tul. \& C. Tul.) Samuels \& Rossmann on hardwoods in North America, Europe and Asia (CAStLEBURY et al., 2006; Hirooka et al., 2013). Similarly, CALE et al. (2017) present the problem of BBD in North America and highlight the negative impact of biotic pests (insects, fungi) on $F$. grandifolia. HirooKA et al. (2013) describe the taxonomic characteristics of the ontogenetic stages of several genera of pathogenic fungi of the family Nectriaceae based on molecular genetics. They also define their ecological requirements and pathogenicity.

In addition to bark/stem damage, leaf scars or lenticels, may also be entry point sites of infection by ascospores, conidia, and mycelia (HANLIN, 1961; BRANDT, 1964; ZALASKY, 1968). The first visible symptom of BBD is the loss of thin branches from the tree crown due to the drying out and breaking of these branches at the site of necrosis. Another feature is the formation of open or closed necrotic wounds on branches and trunks, which may range from small and inconspicuous necrosis, to large open wounds. Necrotic wounds on the bark of beech trees are a symptom and consequence of BBD. For example, fruit bodies of imperfect stages of $N$. coccinea mainly occur on bark in the summer, forming small black circular or elliptical fruit bodies that produce asexual conidia. Perfect stages occur especially in the spring and autumn, when they form easily visible colonies of tiny red-coloured perithecia that grow from bark cracks, around lesions and at the colour boundary of healthy and infected bark (BRANDT, 1964).

The aim of this article is to provide a brief review of all known species of genus Nectria s.l. in Slovakian forests, to describe the situation of the BBD (bark necrosis status) extension in the past and present as well as current knowledge and future challenges in BBD research in terms of the histopathology of affected tissues at the microstructural level.

\section{The occurrence of fungi of the genus Nectria s.l. in Slo- vakia}

In Slovakia, MıHÁL (2011) and MıHÁL et al. (2009) reported the occurrence of 24 species of fungi of the genus Nectria s.l. All records were collected from 112 localities selected within 36 orographic units in Slovakian forests between the years 1990 and 2010 .

In the following list, we enumerate 29 species of fungi of the genus Nectria s.l. that are known from the territory of Slovakia, including four unpublished findings from recent years. The taxonomic nomenclature of species is taken from the database www.mycobank.org.

Bionectriaceae

1. Nectriopsis indigens (Arnold) Diederich et Schroers *

2. Nectriopsis tatrensis (Alstrup) Lisická \& Alstrup +

3. Nectriopsis violacea (J.C. Schmidt ex Fr.) Maire *

4. Paranectria oropensis (Ces.) D. Hawksw. \& Piroz. *

5. Pronectria pertusariicola Lowen *

6. Pronectria tincta (Fuckel) Lowen *

Nectriaceae

1. Corinectria fuckeliana (C. Booth) C. González \& P. Chaverri *

2. Cosmospora coccinea Rabenh. *

3. Cosmospora rishbethii (C. Booth) Rossman \& Samuels

4. Dialonectria episphaeria (Tode) Cooke *

5. Flammocladiella decora (Wallr.) Lechat \& J. Fourn. *

6. Hydropisphaera peziza (Tode) Dumort. *

7. Ilyonectria destructans (Zinssm.) Rossman, L. Lombard \& Crous *

8. Macroconia leptosphaeriae (Niessl) Gräfenhan \& Schroers

9. Nectria cinnabarina (Tode) Fr. *

10. Nectria magnusiana Rehm

11. Nectria tuberculariformis (Rehm ex Sacc.) G. Winter*

12. Neonectria coccinea (Pers.) Rossman \& Samuels *

13. Neonectria ditissima (Tul. \& C. Tul.) Samuels \& Rossman *

14. Neonectria punicea (J. C. Schmidt) Castl. \& Rossman*

15. Penicillifer bipapillatus Samuels *

16. Pseudonectria buxi (DC.) Seifert, Gräfenhan \& Schroers *

17. Sphaerostilbella penicillioides (Corda) Rossman, L. Lombard \& Crous *

18. Stilbocrea gracilipes (Tul. \& C. Tul.) Samuels \& Seifert

19. Stylonectria purtonii (Grev.) Gräfenhan *

20. Thyronectria berolinensis (Sacc.) Seaver*

21. Thyronectria coryli (Fuckel) Jaklitsch \& Voglmayr *

22. Thyronectria sinopica (Fr.) Jaklitsch \& Voglmayr *

Xylariales

1. Monographella nivalis (Schaffnit) E. Müll. *

+ species included in ALSTRUP 1996, * species included in MiHÁl (2011), MiHÁL et al. (2009).

The species $N$. cinnabarina, $N$. coccinea, $N$. ditissima and $D$. episphaeria are common across Slovakia, and they can be very abundant in the presence of suitable substrate and favourable conditions (MıнÁL, 2011). Notably, the taxonomic affinity and synonymy of the species $N$. ditissima and Neonectria galligena are not yet sufficiently discussed and proven in Slovakia; as such we present both fungi as separate species in this work. In the Index Fungorum Database (www.indexfungorum.org), the $N$. ditissima (Tul. \& C. Tul.) Samuels \& Rossman is referred to as a current name, though the species N. galligena (Bres.) Rossman \& Samuels is referred to as a synonym for $N$. ditissima. On the other hand, in the Mycobank Database (www.myco- 
bank.org), the $N$. galligena is referred to as a current name and $N$. ditissima as a synonym for $N$. galligena. We believe that the correct taxonomic distinction between these two species will only be possible on the basis of their molecular and genetic study. In determining these two species, the basic features include the size of bags (ascus) and spores.

$N$. cinnabarina was recorded on wide range of the tree species including Abies alba, Picea abies, Pinus sylvestris, F. sylvatica, Acer platanoides, A. pseudoplatanus, Betula pendula, Carpinus betulus, Quercus spp., Fraxinus excelsior, Salix fragilis, Robinia pseudoacacia, Tilia spp., Malus domestica, Aesculus hippocastanum, Cerasus avium, Corylus avellana, Sambucus nigra, Sorbus aucuparia, Armeniaca vulgaris, Clematis vitalba, Daphne arbuscula, Frangula alnus, Grossularia spp., Juglans regia, Laburnum anagyroides, Rhamnus spp., Ribes alpinum, Rubus spp., Swida sanguinea, Vitis vinifera, and Wisteria spp..

$N$. coccinea fungus was commonly found on F. sylvatica and rarely found on A. pseudoplatanus, F. excelsior and $S$. nigra. Similarly, $N$. ditissima was found only on $F$. sylvatica, M. domestica and Quercus spp. Less frequent is the occurrence of the species C. coccinea ( $F$. sylvatica), $S$. purtonii, H. peziza (F. sylvatica, S. nigra), C. fuckeliana (A. alba, P. abies, P. sylvestris) and N. punicea (F. sylvatica, L. anagyroides) (MıHÁL, 2011).

The species $T$. berolinensis and $N$. violacea can be classified as rare because they were only recorded in Slovakia one or two times (MıнÁL, 2011).

The species: I. destructans, M. nivalis, F. decora, T. sinopica, $N$. tatrensis, $P$. oropensis, $P$. bipapillatus, $P$. pertusariicola, Pseudonectria buxi, S. penicillioides and Tyronectria coryli occur very rarely in Slovakia, with these findings commented on in previous works (e.g., ALSTRUP 1996; MıнÁL 2011; MiHÁL et al. 2009).
We present the following unpublished species for the first findings for Slovakia: (1) C. rishbethii-19 September 2014, Muránska planina Mts, on wood of Pinus nigra, leg. D. Blanár, det. I. Mihál; (2) Macroconia leptosphaeriae 22 September 2017, Kremnické vrchy Mts, on the stems of Urtica dioica, leg. et det. S. Glejdura; (3) N. magnusiana - 30 April 2017, Kremnické vrchy Mts, on the wood of $C$. betulus, leg. et det. S. Glejdura; (4) S. gracilipes - 1 November 2007, Nitrianska pahorkatina upland, on the wood of Quercus spp., leg. et det. S. Husár.

Furthermore, the species Nectria tuberculariformis, $N$. indigens and $P$. tincta can also be classified as very rare in the context of their occurrence period (endangered or extinct). As such, their actual occurrence in the Slovak mycoflora must be confirmed with additional records.

\section{History and current situation of BBD monitoring and research in Slovakia}

An increased occurrence of BBD (manifested through necrotic bark disease) was observed at the end of the 1980s. In several localities, the disease turned into an epiphytotic (Surovec, 1992; CicÁK and Mihál, 2002), not only in Slovakia, but also in Europe and elsewhere (Houston et al., 1979; Gavin and Peart, 1993; Houston, 1994). Similarly, LEONTOVyČ (1997) was the first to note the relevance of this situation in Slovakian forests in 1972-1996. During this period, over 7.5 million $\mathrm{m}^{3}$ of timber became infected, with infections by tracheomycotic diseases making up the majority $\left(5.8 \mathrm{mil} . \mathrm{m}^{3}\right.$ ) of this total. Surovec (1993) also found that the imperfect stages of Nectria spp. fungi infected beech seeds, which caused an infestation of approximately 5,000 ha of young beech trees in 1992 .

BBD caused serious damage to beech forests in Slo-

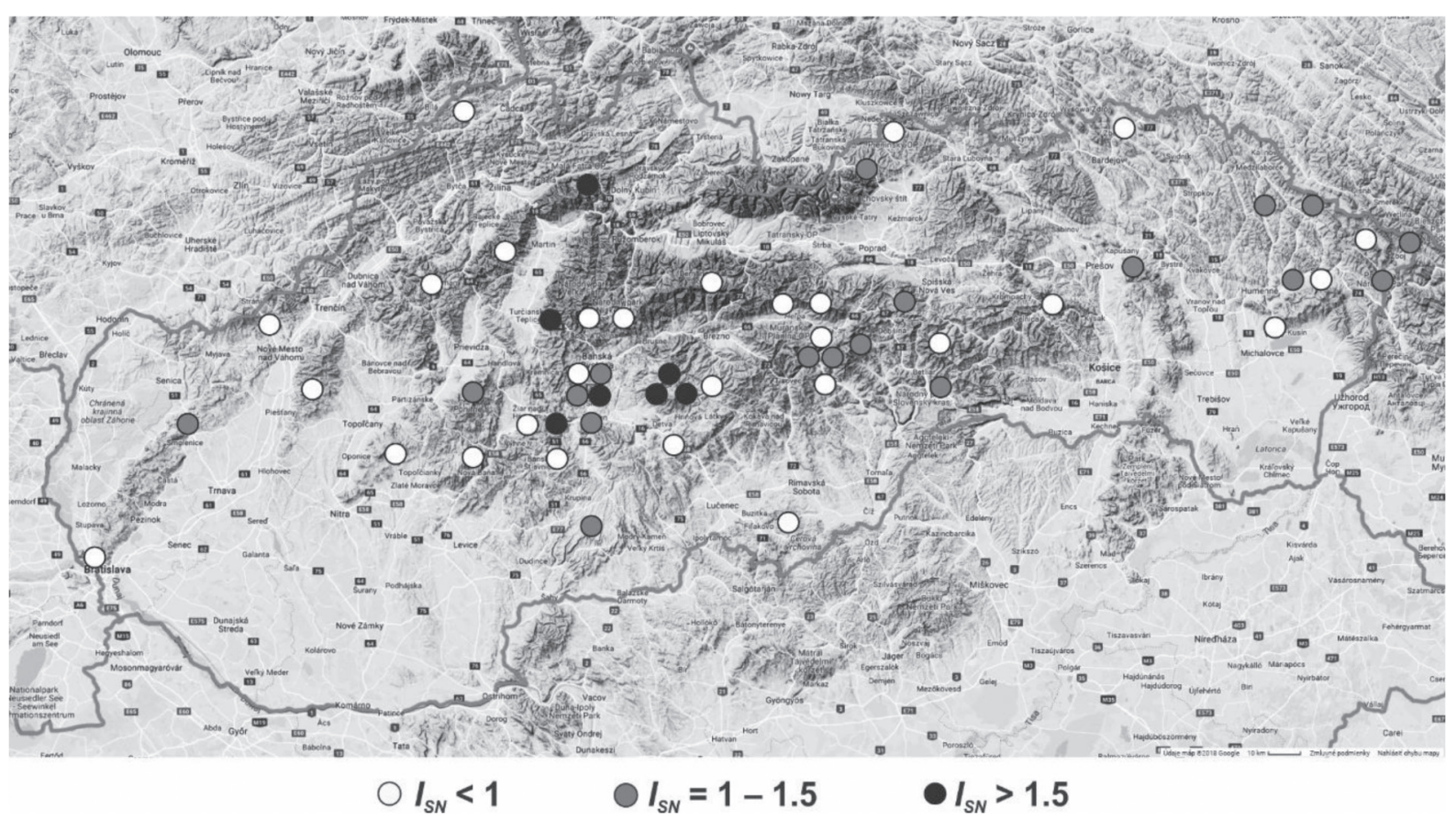

Fig. 1. Distribution of localities with different stem necrotisation index $\left(I_{S N}\right)$ values in the Slovak territory. 
vakia, where they were primarily attacked by $N$. coccinea and N. ditissima (MıнÁL et al., 2009). Juvenile forests were most commonly attacked by $N$. ditissima, which predominantly occurs in the early growth phases (LEONTOVYČ and GÁPER, 1997) with the first noticeable symptoms being visible on branches. By contrast, in adult and old-growth beech forests, the main species recorded were $N$. coccinea and $N$. ditissima (ADAMČík et al., 2016). Susceptibility to infection increased in autumn and winter, when the trees' defence reactions are diminished (ZÚBRIK et al., 2008). Moreover, air pollution, persistent calcium deficiency of the soil and frequent damage to the forest by spring frosts and hailstorms were other probable causes of the epiphytotic decline of juvenile beech forests (Surovec, 1990).

The high aggression of BBD and fungal pathogens represents a relatively large potential risk of its spread, considering the dominant representation of beech stands in Slovakia. The extensive and long-term monitoring evaluated using the original scale proposed by CiCÁK and MIHÁL (1997) had been carried out between 1995 and 2013 in seven different countries of Central (Slovakia, Czech Republic, Poland, Hungary) and South-eastern Europe (Romania, Bulgaria) and contained 121 parent pure and mixed beech forest stands (altitude interval of 320 to 1,550 $\mathrm{m}$ a.s.1.) with over 10,000 trees (age range of 40 to 250 years). A total of 55 monitored localities (altitude interval from 300 to $1,250 \mathrm{~m}$ a.s.1.) with 6,679 beech trees (age range of 20 to 250 years) confirmed an overall favourable state of damage by necrotic bark disease in mature Slovakian forests. However, a wide range of beech stem necrotisation index values was noted $\left(I_{S N}=0.53-1.97\right)$. As much as $49.1 \%$ of Slovakian localities had values of $I_{S N}<1$. Simultaneously, $12.7 \%$ of Slovakian localities had values of $I_{S N}>1.5$. The average $I_{S N}$ value in Slovakia was 1.22. The distribution of $I_{S N}$ values in the Slovak territory is presentedin Fig. 1.

The canopy trees were less affected in terms of BBD severity than sub-canopy and understory trees in both Central and South-eastern Europe. The total explained variability varied considerably in both regions (25.4-73.9\%); however, a higher value was recorded in South-eastern Europe than in Central Europe. Climate and spatial variables had the largest marginal effects on mean BBD severity, followed by stand variables, while site variables had the weakest effects. A positive association was observed between mean annual temperature and mean BBD severity in canopy trees in South-eastern Europe, thus reinforcing the negative effect of climate change on necrosis severity, which might be expected to be more serious under the forecasted climate conditions, primarily in low elevation beech forests. However, promoting tree species diversity in areas with a higher incidence of beech bark necrosis (i.e., at low altitudes in South-eastern Europe) could reduce the future susceptibility of forests to BBD at the regional level (JARČUŠKA et al., 2013).

Recently published data on the BBD dynamics in beech stands revealed a decrease in necrotic disease with increasing distance from the air pollution source (MIHÁL et al., 2019). The significance of the necrotic disease impact was confirmed for the $2^{\text {nd }}$ and $3^{\text {rd }}$ tree classes. Over the
2004-2014 period, $I_{S N}$ the values decreased at all three localities. Moreover, significant positive relationships were observed between the necrotisation of the crown and stem of the same tree at all localities. Accordingly, the trees suffered from necrotic damage to all parts in relation to their current health state. Similarly, BARNA and MiHÁL (2019) examined the dynamics of BBD in beech thicket stands, where they noted the necrosis healing process on the branches and stems of young beech trees.

\section{Current knowledge regarding the histopathology of af- fected tissues}

Detailed studies of the histopathology of tissues of beech wood infected by different Nectria spp. have been scarce in Slovakia and worldwide. The preliminary unpublished findings of structural changes in beech wood tissues infected by fungi of the genus Nectria spp. documented under a scanning electron microscope are presented in Fig. 2 (private archive of paper authors). To date, this type of work has only been conducted on a few tree species such as walnut, apple, aspen, willow and ash (AsHCROFT, 1934; Crowdy, 1949; Zalasky, 1968; SaKamoto et al., 2004; GHASEMKHANI et al., 2016). Although some of these studies were completed many years ago, comprehensive studies focused on beech remain missing. Notably, the spread of disease in beech stands was examined by METZLER et al. (2002), who found a significant spatial correlation between canker incidence in a plantation and the distance to neighbouring diseased shelterwood, with the latter evidently serving as a source of inoculum. Predominant juveniles tended to be more infected, presumably by being more exposed to the inoculum.

In the early stages, BBD infection spreads only in the bark tissues. Later, it also penetrates into the cambium and then into the xylem. The spread of infection in the peripheral tissues of the bark is controlled (to a certain extent) by barriers ("wound phellogens"), which are eventually overcome by mycelia (CROWDY, 1949). Notably, there are two different ways to overcome these barriers. One involves the direct penetration of the pathogen, which occurs approximately 15 days after inoculation (ZALASKY, 1968), while the second is the aggregation of massive sporodochia approximately 110 days after inoculation (GHASEMKHANI et al., 2016). Aggregated sporodochium pushes into the surrounding tissues, leading to the mechanical rupture of the phellogen barrier. However, there is an alternative pathway where the pathogen grows directly through the pit and fibre lumens, thereby overcoming the barrier. The extent and rate of propagation then depend on the balance between pathogen development and host resistance. The spread of the pathogen in the xylem is limited by the formation of tyloses and polyphenols (Crowdy, 1949). Generally, if the pathogen damages the cambium, its activity is locally disrupted. This triggers a series of defensive and healing processes in the wood through the formation of chemically modified barriers (reaction and barrier zones) and tylose formation in vessels (SHAIN, 1967, 1971, 1979; RADEMACHER et al., 1984; BALLESTEROS et al., 2010; VEK et al., 2013). 

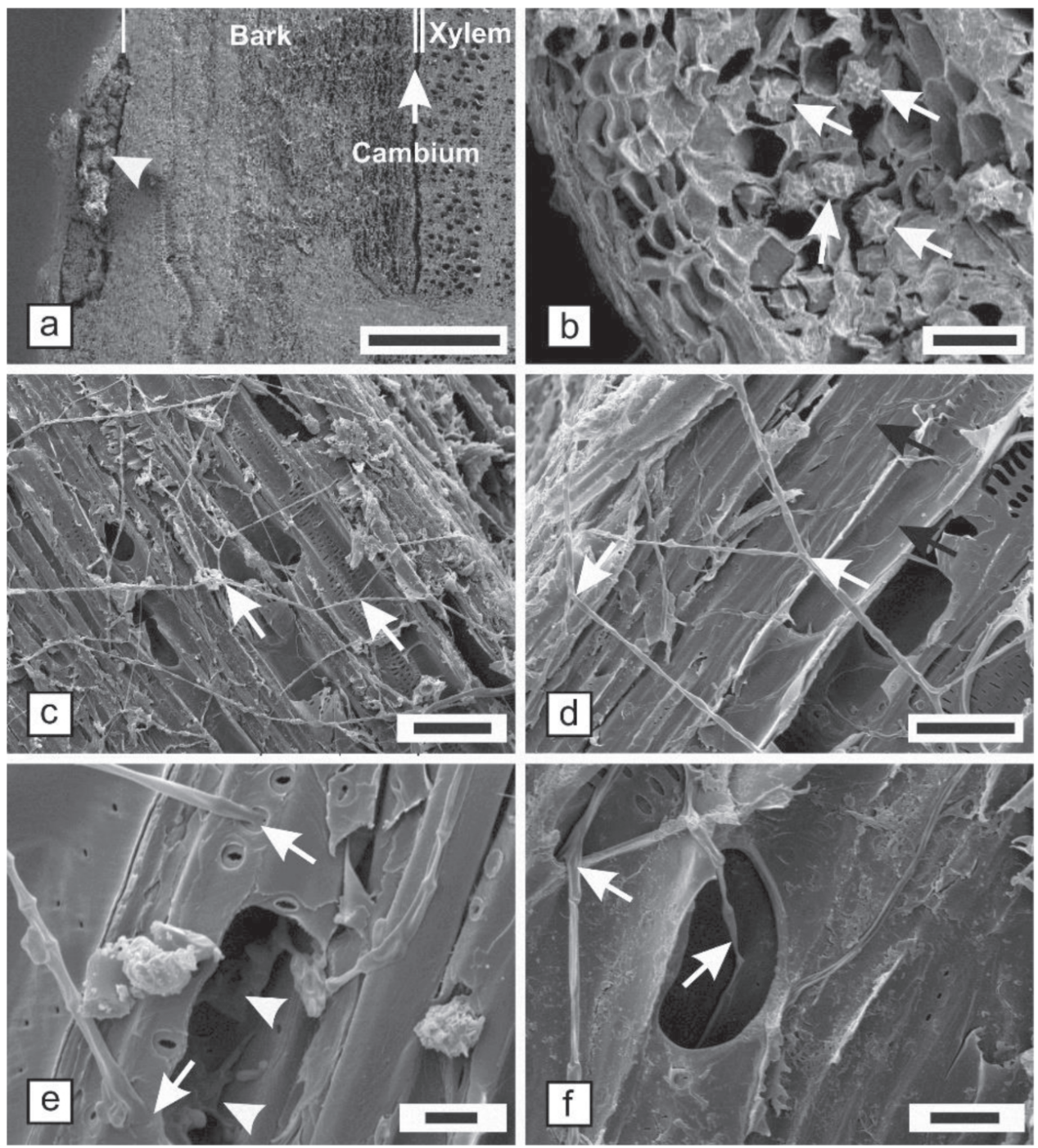

Fig. 2. Scanning electron microscopy micrographs illustrating infected beech bark and xylem tissues attacked by Nectria fungi. a) Mining of the periderm (white arrowhead) by insect larvae allowing better penetration of the infection deeper into the bark tissue. Scale bar $=1 \mathrm{~mm}$. b) Formation of calcium oxalate druse crystals (white arrows) in the outer bark, indicating defence against the spread of infection. Scale bar $=50 \mu \mathrm{m}$. c) The conidiophore branched on an infected xylem surface (white arrows), d) The conidial hyphae in the vessel and fibre lumens and laying on the inner cell walls (black arrow). Scale bar for $\mathrm{c}=200 \mu \mathrm{m}$; scale bar for $\mathrm{d}=50 \mu \mathrm{m}$. e) Conidial hyphae penetrating through the pit aperture without the ability to degrade cell walls (white arrows). Aggregation of conidiospores (white arrows) that is capable of forming conidia and large sporodochia, often leading to the mechanical disruption of xylem structures. Scale bar $=10 \mu \mathrm{m}$. f) Conidiophore entering from the attacked surface into the vessel structure via simple perforation and subsequently spreading along the vessels (white arrows). Scale bar $=20 \mu \mathrm{m}$.

\section{Future challenges in histopathological research}

We aim to enhance scientific knowledge regarding the impacts of different Nectria spp. on anatomical tissues and biochemical changes in the bark and wood of deciduous trees. Determining the effects and factors while avoiding random effects will contribute to a more detailed understanding of the mechanism of defence responses at the anatomical and biochemical levels of cellular tissues. Furthermore, we would like to enhance existing knowledge regarding the spread of necrosis in beech over time. Finally, the impact of soil fertilisation on the ability to resist pathogen invasion will also be investigated.
Through a study of 150 exemplars of one-year-old beech seedlings, the scientific goals include: (1) a detailed investigation of short and long-term histopathological responses of the bark, cambium and xylem of beech tissues (as a model tree) caused by the infection of $N$. coccinea and $N$. ditissima, (2) an investigation of the dynamics of the spread of infection in relation to induced biochemical defence responses; (3) a description of the decomposition strategies of selected pathogens in host tissues in relation to different nutritional complexes in the soil; (4) a comparison of these changes to those resulting from different points of infection penetration into bark (mechanical injuries, lenticels and leaf traces, etc.); and (5) a description 
of changes at the nanostructural level of the cell walls related to degradation progress. Finally, the accuracy of the developed model at predicting changes in beech will be compared with the changes observed in trees growing in the forest sites. The comparison will also be made for other wood species (apple, maple, hornbeam, etc.).

\section{Conclusions}

Although, cyclically recurrent serious epiphytotic damages due to BBD have occurred in the past, a steady state with low and mostly localised occurrence can be observed at present. However, the situation requires increased vigilance and ongoing care for the affected stands as potential areas of BBD extension to healthy trees and stands.

Comprehensive studies describing the spread of the disease at the level of bark and wood tissue microanatomy remain missing from the literature. Therefore, a detailed study of this type facilitate a greater understanding of the spreading strategy of pathogens and their damage to host tissues, mainly in terms of assessing their risk due to altered environmental conditions influenced by global warming.

\section{Acknowledgements}

This work was supported by the Slovak Scientific Grant Agency VEGA No. 2/0101/18 and No. 1/0450/19. This work was also supported by funding from the Slovak Research and Development Agency under the contracts No. APVV-16-0177.

\section{References}

Adamčík, S., Aude, E., Bässler, C., Christensen, M., Dort, K. van, Fritz, Ö., Glejdura, S., Heilmann-Clausen, J., Holec, J., Jančovičová, S., Kunca, V., Lackovičová, A., LÜTH, M., ÓDOR, P., 2016. Fungi and lichens recorded during the Cryptogam Symposium on Natural Beech Forests, Slovakia 2011. Czech Mycology, 68: 1-40.

Alstrup, V., 1996. Nectria tatrensis sp. nov. and other lichenicolous fungi found on the bryo-lichenological excursion in Slovakia 1993. Biologia, Bratislava, 51: 13-14.

AshCroft, J.M., 1934. European canker of Black Walnut and other trees. Bulletin of the West Virginia Agricultural Experiment Station, 261: 1-52.

Ballesteros, J., Stoffel, M., Bodoque, J., Bollshweiller, M., Hitz, O., Diez- Herrero, A., 2010. Changes in wood anatomy in tree rings of Pinus pinaster Ait. following wounding by flash floods. Tree-Ring Research, 66: 93103.

BARna, M., MináL, I., 2019. Bark necroses disease in a beech thicket. Plant Protection Science, 55: 181-190.

BRANDT, R.W., 1964. Nectria canker of hardwoods. Forest Pest Leaflet, 84. Washington, D.C.: Department of Agriculture, Forest Service. 7 p.

Cale, J.A., Ashby, A.W., West, J.L., Teale, S.A., Johnston, M.T., Castello, J.D., 2015a. Scale insects, decay and canker fungi in American beech. Forest Pathology, 45: $71-75$.

Cale, J.A., Garrison-Johnston, M.T., Teale, S.A., CasteLLO, J.D., 2017. Beech bark disease in North America: over a century of research revisited. Forest Ecology and Management, 394: 86-103.

Cale, J.A., Teale, S.A., Johnston, M.T., Boyer, G.L., Perri, K.A., Castello, J.D., 2015b. New ecological and physiological dimensions of beech bark disease development in aftermath forests. Forest Ecology and Management, 336: 99-108.

Castlebury, L.A., Rossman, A.Y., Hyte, A.S., 2006. Phylogenetic relationships of Neonectria/Cylindrocarpon on Fagus in North America. Canadian Journal of Botany, 84: 1417-1433.

CıCÁK, A., MıнÁL, I., 1997. Metodika hodnotenia nekrotizácie kôry kmeňov buka [Metodology of evaluating bark necrosis on beech stems]. Lesnictví - Forestry, 43:104109.

Cicák, A., MıнÁL, I., 2002. State of necrotic disease of beech stands in Slovakia. Mikologija i Fitopatologija, 36: 93105.

Crowdy, S.H., 1949. Observations on apple canker III. The anatomy of the stem canker. Annals of Applied Biology, 36: 483-495.

FunK, G., 1940. Buchenstudien im Apennin [Beech studies in the Apennines]. Mitteilungen der Deutschen Dendrologischen Gesellschaft, 53: 230-250.

Gavin, D.G., PEART, D.R., 1993. Effects of beech bark disease on the growth of American beech (Fagus grandifolia). Canadian Journal of Forest Research, 23: 1566-1575.

Ghasemkhani, M., A. Holefors, S., Marttila, K., Dalman, A., ZborowsKa, M., RuR, J., ReEs-George, H., Nybom, K.R., Everett, R.W., Scheper, A., Garkava-Gustavsson, L., 2016. Real-time PCR for detection and quantification, and histological characterization of Neonectria ditissima in apple trees. Trees, 30: 1111-1125.

Hanlin, R.T., 1961. Studies in the genus Nectria. II. Morphology of N. gliocladioides. American Journal of Botany, 48: 900-908.

Hartig, T., 1878. Anatomie and Physiologie der Holzpflanzen [Anatomy and physiology of wood plants]. Berlin: J. Springer. $412 \mathrm{p}$.

Hirooka, Y., Rossman, A.Y., Zhuang, W.-Y., Salgado-ZALAZAR, C., Charverri, P., 2013. Species delimitation for Neonectria coccinea group including the causal agents of beech bark disease in Asia, Europe, and North America. Mycosystema, 32: 485-517.

Houston, D.R., 1994. Temporal and spatial shift within the Nectria pathogen complex associated with beech bark disease of Fagus grandifolia. Canadian Journal of Forest Research, 24: 960-968.

Houston, D.R., Parker, E.J., Perrin, R., Lang, K.J., 1979. Beech bark disease: a comparison of the disease in North America, Great Britain, France, and Germany. European Journal of Forest Pathology, 9: 199-211.

IvaNOvá, H., 2018. Identification and characterization of the fungus Dothiorella sarmentorum on necrotic shoots of declining ash in Slovakia. Folia Oecologica, 45: 53-57.

JarČUŠKa, B., MiháL, I., CiCÁK, A., Tsakov, H., 2013. Beech bark necrosis: partitioning the environmental and spatial variation of the damage severity in Central and SouthEastern Europe. Annals of Forest Research, 56: 317-338. 
KacprzyK, M., Matsiakh, I., Musolin, D.L., Selikhovkin, A.V., Baranchikov, Y.N., Burokiene, D., Cech, T., TalGØ, V., Vettraino, A.M., Vannini, A., Zambounis, A., Prospero, S., 2017. Damage to stems, branches and twigs of broadleaf woody plants. In Roques, A., Cleary, M., Matsiakh, I., Eschen, R. (eds). Field guide for the identification of damage on woody sentinel plants. Wallingford: CAB International, p. 104-134.

LeONTOVyČ, R., 1992. Význam rodu Ophiostoma na listnatých drevinách $\mathrm{v}$ súčasných zmenených ekologických podmienkach Slovenska [Importance of the genus Ophiostoma in the current ecological conditions in Slovakia]. In Holubová, V., Prášil, K. (eds). Ophiostomatales - výsledky současného taxonomického a fytopatologického výzkumu. Praha: ČSVSM, p. 35-49.

LEONTOVYČ, R., 1997. Výskyt významných hubových ochorení v lesoch Slovenska za obdobie rokov 1972-1996 [The occurrence of significant fungi diseases in Slovakian forests during period 1972-1996]. In Drevoznehodnocujúce huby, 97. Zvolen: Technická univerzita, p. 13-20.

LeONTOVyČ, R., Gáper, J., 1997. Hlavné fytopatologické problémy v lesoch Slovenska a možnosti ich eliminácie [Main phytopathological problems in Slovakian forests and possibilities of their elimination]. In Aktuálne problémy v ochrane lesa' 97. Zborník referátov z celoslovenského seminára, ktorý sa konal 7.-8. apríla 1997 v Banskej Štiavnici. Zvolen: Lesnícky výskumný ústav, p. 7-16.

Metzler, B., Meierjohann, F., Kublin, E., von Wühlisch, G., 2002. Spatial dispersal of Nectria canker of beech in an international provenance trial. Forest Pathology, 32: $137-144$.

MiнÁL, I., 2011. Occurrence of fungi of the genus Nectria s.l. (Ascomycota, Hypocreales, Bionectriaceae, Nectriaceae) in Slovakia. Folia Oecologica, 38: 80-88.

Minál, I., Cicák, A., Tsakov, H., Petkov, P., 2009. Occurrence of species of the Nectria s.l. (Bionectriaceae, Nectriaceae, Hypocreales, Ascomycetes) in Central and South-eastern Europe. Folia Oecologica, 36: 32-38.

Minál, I., Marušák, R., Barna, M., 2019. Dynamics of Fagus sylvatica $\mathrm{L}$. necrotization under different pollutant load conditions. Polish Journal of Environmental Studies, 28: $2755-2763$.

Rademacher, P., Bauch, J., Shigo, A.L., 1984 Characteristics of xylem formed after wounding in Acer, Betula, and Fagus. Iawa Bulletin, 5: 141-150.

Rapp, A.O., Behrmann, K., 1998. Preparation of wood for microscopic analysis after decay testing. Holz als Rohund Werkstoff, 56: 277-278.
SAKamoto, Y., Yamada, Y., SAno, Y., TAmai, Y., Funada, R., 2004. Pathological anatomy of Nectria canker on Fraxinus mandshurica var. Japonica. IAWA Journal, 25: 165-174.

SHAIN, L., 1967. Resistance of sapwood in stems of Loblolly pine to infection by Fomes annosus. Phytopathology, 57: 1034-1045.

Shain, L., 1971. The response of sapwood of Norway spruce to infection by Fomes annosus. Phytopathology, 61: 301307.

ShaIn, L., 1979. Dynamic responses of differentiated sapwood to injury and infection. Phytopathology, 69: 1143-1147.

Steiner, K.C., Westbrook, J.W., Hebard, F.V., Georgi, L.L., Powell, W.A., Fitzsimmons, S.F., 2017. Rescue of American chestnut with extraspecific genes following its destruction by a naturalized pathogen. New Forests, 48: 317-336.

Surovec, D., 1990. Príznaky a príčiny chradnutia mladých bučín na Slovensku [Symptoms and causes declining of young beech forests in Slovakia]. Les, 46: 12-13.

Surovec, D., 1992. Tracheomycoses of young beech stands from natural regeneration. Acta Instituti Forestalis Zvolen, 8: 97-105.

Surovec, D,. 1993. Vývoj nekróz v mladých bučinách [Development of necrosis in juvenile beech forests]. In Zborník referátov Ochrana lesov proti škodlivým činitel’om. Zvolen: Lesnícky výskumný ústav, p. 45-51.

Vek, V., Oven, P., Humar, M., 2013. Phenolic extractives of wound-associated wood of beech and their fungicidal effect. International Biodeterioration \& Biodegradation, 77: 91-97.

Zalasky, H., 1968. Penetration and initial establishment of Nectria galligena in aspen and peachleaf willow. Canadian Journal of Botany, 46: 57-60.

ZúBrik, M., KunCA, A., NovotnÝ, J., 2008. Atlas poškodenia lesných drevin. Hmyz a huby [Atlas of damage the forest tree species. Insect and fungi]. Zvolen: Národné lesnícke centrum - Lesnícky výskumný ústav. 178 p.

YamadA, T., 2001. Defense mechanisms in the sapwood of living trees against microbial infection (review). Journal of Forest Research, 6: 127-137.

YAMAJI, K., ICHIHARA, Y., 2012. The role of catechin and epicatechin in chemical defense against damping-of fungi of current-year Fagus crenata seedlings in natural forest. Forest Pathology, 42: 1-7.

Received October 11, 2019 Accepted February 12, 2020 